\title{
Propofol induces apoptosis by activating caspases and the MAPK pathways, and inhibiting the Akt pathway in TM3 mouse Leydig stem/progenitor cells
}

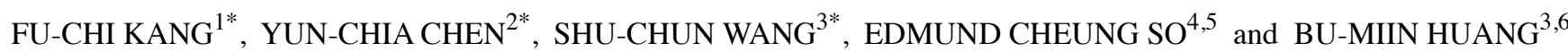 \\ ${ }^{1}$ Department of Anesthesia, Chi Mei Medical Center, Chiali, Tainan 71004; ${ }^{2}$ Department of Anatomy, \\ School of Medicine, Kaohsiung Medical University, Kaohsiung 80708; ${ }^{3}$ Department of Cell Biology and Anatomy, \\ College of Medicine, National Cheng Kung University, Tainan 70101; ${ }^{4}$ Department of Anesthesia, \\ An Nan Hospital, China Medical University, Tainan 70965; ${ }^{5}$ Graduate Institute of Medical Sciences, \\ Chang Jung Christian University, Tainan 71101; ${ }^{6}$ Department of Medical Research, \\ China Medical University Hospital, China Medical University, Taichung 40406, Taiwan, R.O.C.
}

Received November 11, 2019; Accepted April 6, 2020

DOI: $10.3892 /$ ijmm.2020.4584

\begin{abstract}
Propofol is an anesthetic agent moderating GABA receptors in the nervous system. A number of studies have demonstrated that propofol exerts a negative effect on neural stem cell development in the neonatal mouse hippocampus. However, to the best of our knowledge, there is no study available to date illustrating whether neonatal exposure to propofol affects Leydig stem/progenitor cell development for normal male reproductive development and functions, and the regulatory mechanism remains elusive. In the present study, TM3 cells, a mouse Leydig stem/progenitor cell line, was treated with propofol. The data illustrated that propofol significantly reduced TM3 cell viability. TM3 subG1 phase cell numbers were significantly increased by propofol assayed by flow cytometric analysis. Annexin V/PI double staining assay of the TM3 Leydig cells also demonstrated that propofol increased TM3 cell apoptosis. In addition, cleaved caspase-8, -9 and -3 and/or poly(ADP-ribose) polymerase (PARP) were significantly activated by propofol in the TM3 cells. Furthermore, the expression levels of phospho-JNK, phospho-ERK1/2 and phospho-p38 were activated by propofol
\end{abstract}

Correspondence to: Professor Bu-Miin Huang, Department of Cell Biology and Anatomy, College of Medicine, National Cheng Kung University, 1 University Road, Tainan 70101, Taiwan, R.O.C.

E-mail: bumiin@mail.ncku.edu.tw

Professor Edmund Cheung So, Graduate Institute of Medical Sciences, Chang Jung Christian University, 1 Changda Road, Gueiren, Tainan 71101, Taiwan, R.O.C.

E-mail: edmundsotw@gmail.com

*Contributed equally

Key words: propofol, TM3 Leydig cells, apoptosis, caspase, MAPK pathway, Akt pathway in the TM3 cells, indicating that propofol induced apoptosis through the mitogen-activated protein kinase (MAPK) pathway. Additionally, propofol diminished the phosphorylation of Akt to increase the apoptosis of TM3 cells. On the whole, the findings of the present study demonstrate that propofol induces TM3 cell apoptosis by activating caspases and MAPK pathways, as well as by inhibiting the Akt pathway in TM3 cells. These findings illustrate that propofol affects the viability of Leydig stem/progenitor cells possibly related to the development of the male reproductive system.

\section{Introduction}

Propofol is always utilized as a sedative and anesthetic agent before medical procedures, which can modulate different GABA receptors in the central nervous system (1). Various studies have demonstrated that propofol can induce developmental neurotoxicity in mice $(2,3)$ and induces the apoptosis of neuronal stem cells in the hippocampus of neonatal mice (4). Thus, the reproductive system in the fetal period can also be highly possible affected by anesthetic agents. It has been demonstrated that Leydig cells are derived from the neural system (5) and the essential role of Leydig cells is to produce testosterone (6). For normal reproductive functions in males, Leydig stem/progenitor cells are essential for testis development in the fetal period (7). It has been demonstrated that different factors influence the development of Leydig stem/progenitor cell in the fetal period, resulting in infertility (7). However, it remains unknown as to whether propofol induces the death of Leydig stem/progenitor cells, which would suppress male reproductive function and development.

Cell number regulation is essential in tissue homeostasis controlled by cell death, proliferation and differentiation (8). Cell death can be categorized into 3 categories based on morphological appearance, which includes necrosis, apoptosis and autophagy (9). Cell apoptosis is uniformly featured with nuclear condensation and fragmentation, cell shrinking, membrane blebbing and separation of the cellular components 
into apoptotic bodies (10). Apoptosis is regulated by 2 pathways, the extrinsic and intrinsic pathways, respectively (11). The extrinsic pathway is known as the death receptor pathway, stimulated by the activation of death receptors with pro-apoptotic ligands, such as Fas ligand (FasL), tumor necrosis factor (TNF)- $\alpha$ and TNF-related apoptosis-inducing ligand (TRAIL). As ligands bind, the intracellular death domains of the receptors associate with Fas-associated death domain (FADD), resulting in the death-induced signaling complex (DISC) recruitment, and hence leading to caspase- 8 activation and further triggering caspase- 3 or -7 activation (12). The intrinsic pathway is associated with the mitochondrial pathway, which is triggered by a number of stimuli (chemotherapeutic agents, radiation and growth factor withdrawal) leading to the release of cytochrome $c$ from the mitochondria into the cytosol (13). Cytochrome $c$ binds with the adapter molecule, apoptotic protease activating factor 1 (Apaf-1), and recruits procaspase- 9 to form the apoptosome to further activate caspase-9 and caspase-3, orchestrating apoptosis (14). Both the intrinsic and extrinsic pathways can lead to the cleavage of poly(ADP-ribose) polymerase (PARP), which impedes the effects of DNA repair (11).

The mitogen-activated protein-serine/threonine kinase (MAPK) pathway plays a key role in regulating cell proliferation, growth, differentiation, invasion, migration and apoptosis (15). MAPKs include extracellular-regulated kinase (ERK)1/2, Janus kinase (JNK) and p38, which can be stimulated by phosphorylation, commencement with MAPK kinase kinase kinase (MAP3K) activation to control cell fate (16). The Akt signaling pathway is considered as a pro-survival pathway, which can inhibit apoptotic cascades and activate pro-survival signals (17). The Akt pathway can inhibit a number of pro-apoptotic Bcl-2 family members (Bad, Bax and Bim) and positively regulate anti-apoptotic pathways [nuclear factor $(\mathrm{NF})-\kappa \mathrm{B}$ transcription factor], promoting the transcription of a number of anti-apoptotic genes, such as Bcl-2 and $\mathrm{Bcl}-\mathrm{xL}$ (18). It has been illustrated that the reduction of Akt expression can induce the apoptosis of various cells (19).

TM3 cells are derived from 11-13-day-old testicular interstitial cells of neonatal BALB/c mouse, which can be stimulated by luteinizing hormone (LH) to secret testosterone (20-22), and TM3 cells exhibit progenitor cell characteristics $(7,20)$. Consequently, TM3 cells are appropriate for use in the investigation of the apoptotic effects of propofol with mechanistic analyses. In the present study, propofol induced TM3 progenitor cell membrane blebbing with detachment phenomena, a decrease in cell number, activated the caspase cascade, activated MAPK pathways and inhibited Akt pathway, which promoted cell apoptosis. The findings of the present study demonstrated that propofol regulates TM3 mouse Leydig stem/progenitor cell apoptosis, which deepens the knowledge of the mechanisms through which anesthetic agent exposure can affect testicular normal development.

\section{Materials and methods}

Chemicals and reagents. Propofol, penicillin-streptomycin, ethylene diamine tetraacetic acid (EDTA), propidium iodide (P), MTT, RNase A, 30\% acrylamide/Bis-acrylamide solution, Waymouth MB 752/1 medium, sodium orthovanadate, monoclonal antibody against $\beta$-actin (\#A5441) and Triton X-100 were purchased from Sigma-Aldrich; Merck KGaA. EGTA, Tween 20, dimethyl sulfoxide (DMSO) and DS were purchased from Merck KGaA. An Annexin V-fluorescein isothiocyanate (FITC) apoptosis detection kit was purchased from Strong Biotech Corporation. Dulbecco's modified Eagle medium/F12, fetal bovine serum and trypsin-EDTA were purchased from Gibco; Thermo Fisher Scientific Inc. Potassium chloride, sodium chloride, Tris base and glycine 4-(2-hydroxyethyl)-1-piperazineethanesulfonic acid were purchased from J.T. Baker (Avantor Performance Materials). Donkey anti-rabbit (NEF81200-1EA) and anti-mouse (NEF82200-1EA) IgG conjugated with horseradish peroxidase (HRP) were purchased from PerkinElmer, Inc. A Micro BCA protein assay kit was purchased from Thermo Fisher Scientific, Inc. An enhanced chemiluminescence detection kit was purchased from EMD Millipore. Polyclonal antibodies against cleaved caspase-8 (\#9429; 1/1,000), cleaved caspase-9 (\#9509; $1 / 1,000)$, cleaved PARP (\#9542; 1/1,000), phospho-JNK (\#9251; 1/4,000), JNK (\#9252; 1/1,000), phospho-ERK1/2 (\#9101; 1/4,000), ERK1/2 (\#9102; 1/4,000), phospho-p38 (\#9215; 1/1,000), p38 (\#9212; 1/4,000), phospho-Akt (\#9271; 1/4,000) and Akt (\#9272; 1/1,000) and phospho-mechanistic target of rapamycin (mTOR) (\#2971; 1/1,000) were purchased from Cell Signaling Technology, Inc. ISOTON ${ }^{\text {TM }}$ II Diluent was purchased from Beckman Coulter, Inc. Monoclonal antibody against cleaved caspase-3 (\#9661; 1/1,000) was purchased from Cell Signaling Technology, Inc.

Cells and cell culture. TM3 cells were obtained from ATCC and sustained in DMEM/F12 medium with $10 \% \mathrm{FBS}$ at $37^{\circ} \mathrm{C}$ in a humidified incubator containing $95 \%$ air and $5 \% \mathrm{CO}_{2}$ for all experiments.

Morphological observation. TM3 cells were seed at $6 \times 10^{5} / \mathrm{ml}$ and treated with various concentrations of propofol $(0,300$, 350 and $400 \mu \mathrm{M}$ ) for $3 \mathrm{~h}$, respectively. Propofol was diluted with DMSO. The changes in cell morphology were then investigated with an Olympus CK40 light microscopy at x100 magnification and the images were logged using an Olympus DP20 digital camera (Olympus Corporation).

MTT cell viability assay. MTT assay is a colorimetric assay for measuring cell viability (23). TM3 cells were cultured at $8 \times 10^{3}$ cells. After reaching 70-80\% confluence, cells were treated with various concentrations of propofol $(0,10,50$, $100,300,400,500$ and $600 \mu \mathrm{M}$ ) for 1, 3, 6, 12 and $24 \mathrm{~h}$, respectively. Subsequently, each well was supplemented with MTT $(0.5 \mathrm{mg} / \mathrm{ml})$ for different periods of time followed by incubation at $37^{\circ} \mathrm{C}$ for $4 \mathrm{~h}$. The media was discarded and $50 \mu \mathrm{l}$ DMSO were added to dissolve the crystals using a shaker to vibrate the plate at $37^{\circ} \mathrm{C}$ for $20 \mathrm{~min}$ in the dark. Cell viability was examined at $\lambda=570 \mathrm{~nm}$ using a VersaMax ELISA reader (Molecular Devices, Inc.), as previously described (23).

Cell cycle analysis. TM3 cells were seeded at $6 \times 10^{5}$ with $2 \mathrm{ml}$ culture medium, and treated with various concentrations of propofol $(0,100,300$ and $400 \mu \mathrm{M})$ for 3, 6, 12 and $24 \mathrm{~h}$, respectively. Cells were collected through trypsin digestion and centrifugation $\left(400 \mathrm{x}\right.$ g for $12 \mathrm{~min}$ at $4^{\circ} \mathrm{C}$ ), and washed with 


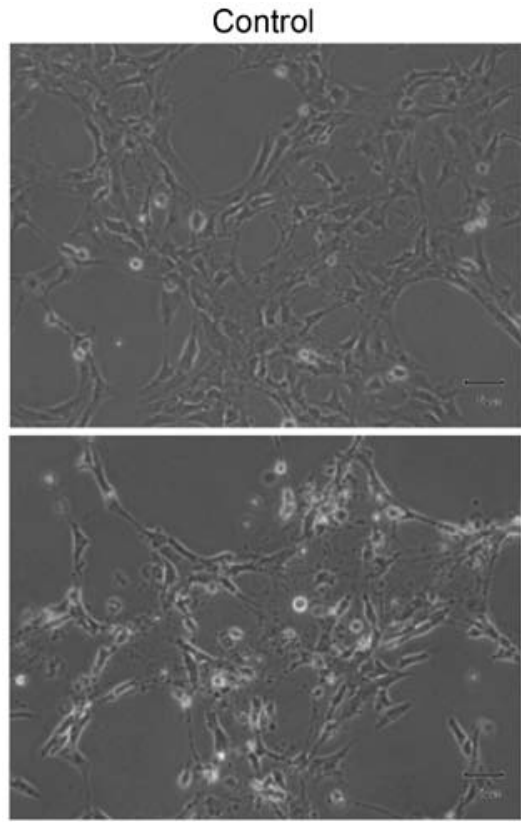

$350 \mu \mathrm{M}$

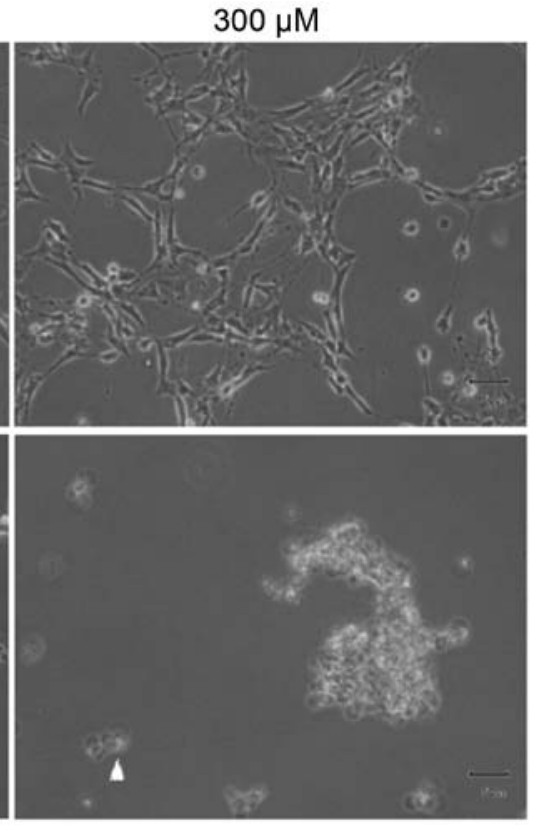

$400 \mu \mathrm{M}$

Figure 1. Cell morphology is altered by propofol associated with the death of TM3 cells. Cells were treated with various concentrations of propofol (control, 300,350 and $400 \mu \mathrm{M}$ ) for $3 \mathrm{~h}$, respectively, and the morphological changes were examined by light microscopy (scale bar, $50 \mu \mathrm{m}$; white arrowhead, cells with membrane blebbing).

isoton II and fixed with $70 \%$ ethanol for at least $2 \mathrm{~h}$ at $-20^{\circ} \mathrm{C}$. Following fixation, cells were washed with cold isoton II and collected by centrifugation $\left(400 \mathrm{x}\right.$ g for $12 \mathrm{~min}$ at $4^{\circ} \mathrm{C}$ ). Cell suspensions were then mixed with $100 \mu \mathrm{g} / \mathrm{ml}$ RNase and stained with $40 \mu \mathrm{g} / \mathrm{ml}$ propidium iodine (PI) solution for $30 \mathrm{~min}$ at $25^{\circ} \mathrm{C}$. Stained cells were determined at $\lambda=488 \mathrm{~nm}$ for PI detection by FACScan flow cytometer (BD Biosciences). SubG1 phase cells with lower DNA contents are considered as apoptotic cells (24). The percentages of sub-G1, S and G2/M phase cells were analyzed using FACStation v6.1x and Modfit LT v3.3 software (BD Biosciences).

Annexin V/PI double staining assay. After the TM3 cells were collected by trypsin, cell suspensions were centrifuged (400 x g for $12 \mathrm{~min}$ at $4^{\circ} \mathrm{C}$ ). The pellets were resuspended with cold isoton II and centrifuged again ( $400 \mathrm{x} \mathrm{g}$ for $12 \mathrm{~min}$ at $4^{\circ} \mathrm{C}$ ), and then mixed with $100 \mu \mathrm{l}$ staining solution for $15 \mathrm{~min}$ at $25^{\circ} \mathrm{C}$ following the user's manual of Annexin V-FITC apoptosis detection kit from Srong Biotech Corporation. Stained cells were determined at $\lambda=488 \mathrm{~nm}$ excitation using $515 \mathrm{~nm}$ band pass filter for FITC detection and $>600 \mathrm{~nm}$ band pass filter for PI detection using a FACScan flow cytometer (BD Biosciences). The double-positive cells (late apoptotic), Annexin V single-positive cells (early apoptotic), PI single-positive cells (necrotic) and double-negative cells (viable) are illustrated in 4 quadrants $(25,26)$. The percentage of cells in the 4 quadrants were analyzed using FACStation v6.1x software.

Protein extraction and western blot analysis. Following the treatments, cells in the medium were removed and washed with cold PBS. Attached cells were lysed by $20 \mu 1$ lysis buffer (150 mM NaCl, $20 \mathrm{mM}$ Tris pH7.5, $1 \mathrm{mM}$ EGTA, $1 \mathrm{mM}$ EDTA, $1 \%$ Triton $\mathrm{X}-100,1 \mathrm{mM}$ sodium orthovanadate and $2.5 \mathrm{mM}$ sodium pyrophosphate) with proteinase inhibitor cocktail (cat. no. P5655; Sigma-Aldrich; Merck KGaA). The pellets were then resuspended with $10 \mu 1$ lysis buffer and centrifuged at $12,000 \times \mathrm{g}$ for $12 \mathrm{~min}$ at $4^{\circ} \mathrm{C}$. The supernatants were saved and stored at $-80^{\circ} \mathrm{C}$. The protein concentrations of cell lysates were analyzed by Lowry assay (27).

For western blot analysis, $30 \mu \mathrm{g}$ protein were separated by $12 \%$ SDS-PAGE gel with running buffer (0.1\% SDS, $192 \mathrm{mM}$ glycine and $25 \mathrm{mM}$ Tris; $\mathrm{pH} 8.3$ ) at $25^{\circ} \mathrm{C}$, and electrophoretically transferred to polyvinylidene difluoride membranes at $4^{\circ} \mathrm{C}$. After blocking the membranes with $1 \%$ milk at $25^{\circ} \mathrm{C}$ for $3 \mathrm{~h}$, the membranes were incubated with primary antibodies for $24 \mathrm{~h}$ at $4^{\circ} \mathrm{C}$. The membranes were then washed 3 times and incubated with HRP-conjugated secondary antibodies $(1 / 2,000)$ at $25^{\circ} \mathrm{C}$ for $1 \mathrm{~h}$. Bands were detected using an enhanced chemiluminescence kit and the UVP EC3 BioImaging system (UVP, LLC). Quantification of the western blotting data was performed using ImageJ version 1.50 software (National Institutes of Health) (28).

Statistical analysis. Data are presented as the means \pm standard error of the mean among 3 experiments. Significance of differences between the control and treatment groups were determined by one-way analysis of variance followed by all pairs Tukey's honestly significant difference (HSD) post-hoc test comparisons. Statistical analysis was accomplished using GraphPad Prism 6 software (GraphPad Software, Inc.). $\mathrm{P}<0.05$ was considered to indicate a statistically significant difference.

\section{Results}

Cell morphology is altered by propofol associated with the death of TM3 cells. TM3 cells were treated with various concentrations $(0,300,350$ and $400 \mu \mathrm{M})$ of propofol (Fig. 1) for $3 \mathrm{~h}$, respectively. Morphological changes of cells were 


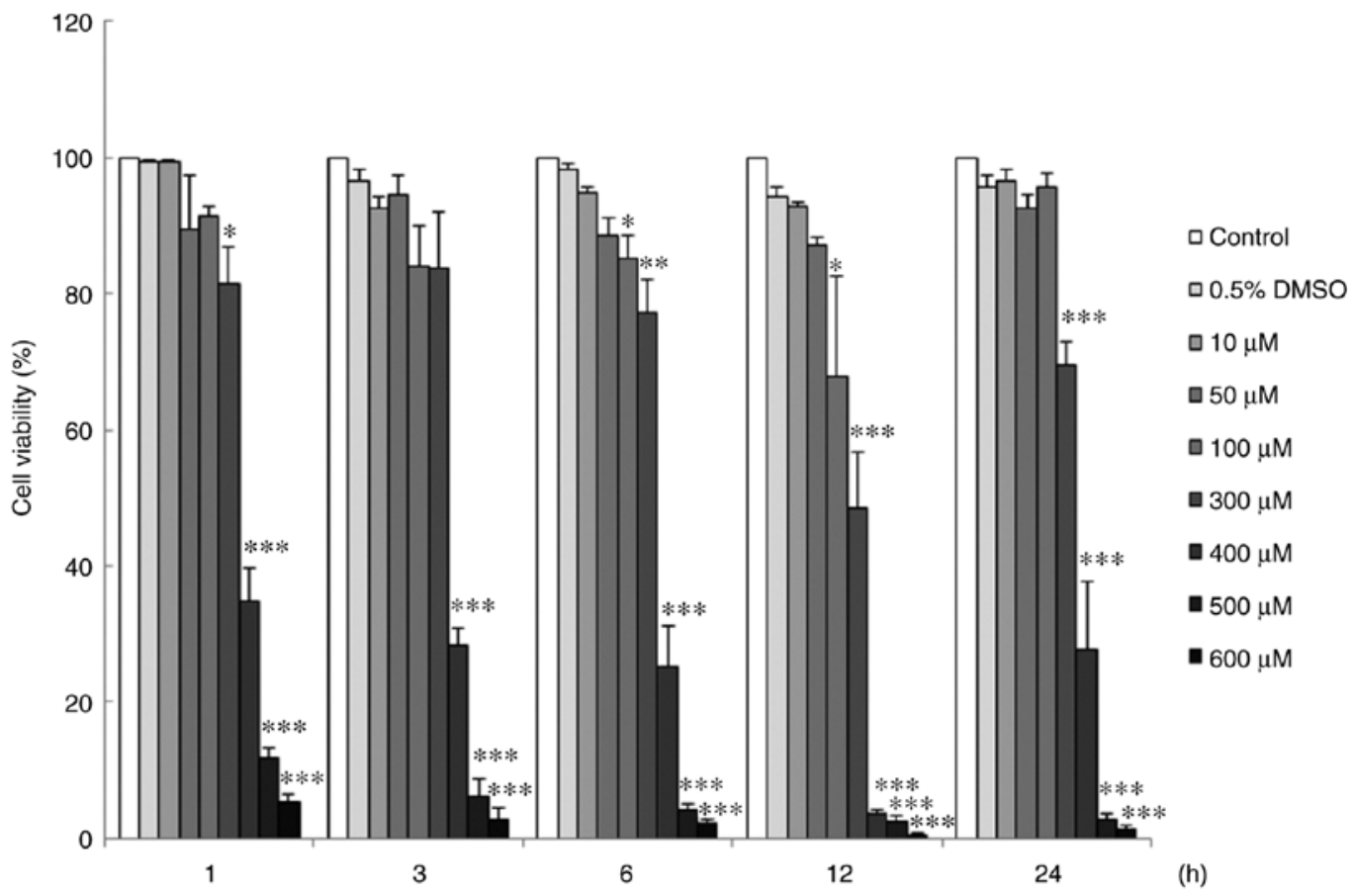

Figure 2. Viability of TM3 cells was reduced by propofol in a time- and dose-dependent manner. Cells were treated with 0 (Control), $0.5 \%$ DMSO, 10, 50, 100, $300,400,500$ and $600 \mu \mathrm{M}$ propofol for 1,3,6,12 and $24 \mathrm{~h}$, respectively. MTT viability assay was used to determine cell viability. Data are illustrated as a percentage of cell growth relative to the control groups. Each data point represents the mean \pm SEM of 3 separate experiments. ${ }^{*} \mathrm{P}<0.05,{ }^{* * *} \mathrm{P}<0.01$ and ${ }^{* * * *} \mathrm{P}<0.001$ indicate statistically significant differences compared to the control group. DMSO, dimethyl sulfoxide.


Figure 3. Propofol regulates the TM3 cell cycle. Cells were treated with 0 (Control), 100, 300 and $400 \mu \mathrm{M}$ propofol for 3, 6, 12 and $24 \mathrm{~h}$, respectively. Cell were then fixed and stained with propidium iodide (PI) for cell cycle analysis, and (A and B) subG1 and (A and C) G2/M phase cells were then analyzed and illustrated, respectively. SubG1 phase cells contain less DNA content compared to normal cells, indicating apoptosis. Each data point represents the mean \pm SEM of 3 separate experiments. ${ }^{*} \mathrm{P}<0.05$ and ${ }^{* * *} \mathrm{P}<0.001$ indicate statistically significant differences compared to the control group. 

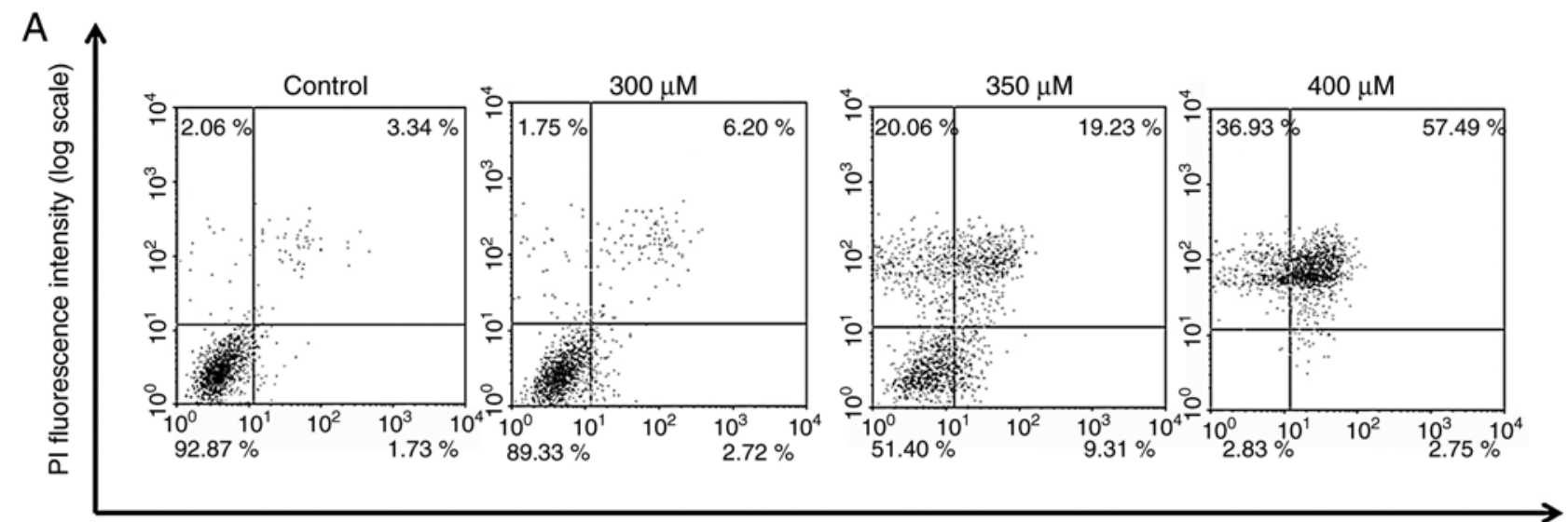

Annexin V-FITC fluorescence intensity (log scale)
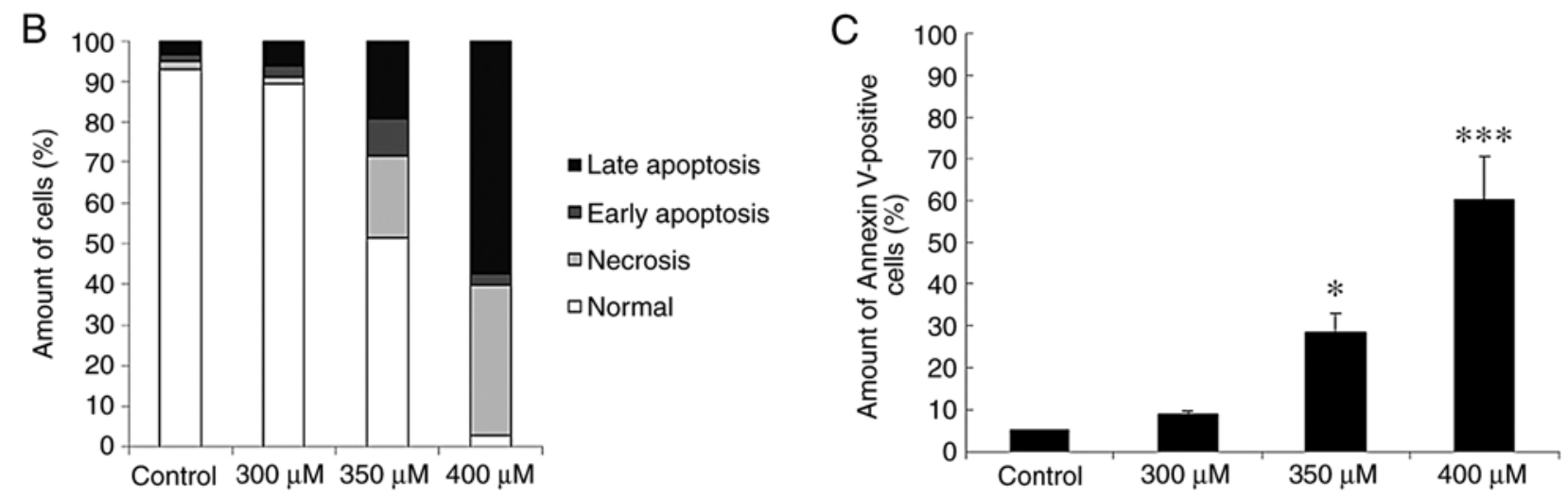

Figure 4. Propofol induces the apoptosis of TM3 cells. Cells were treated with 0 (Control), 300, 350 and $400 \mu \mathrm{M}$ propofol for $24 \mathrm{~h}$, respectively. (A) The apoptotic phenomenon of propofol-induced cells was examined by Annexin V/PI double staining assay. (B) The percentages of Annexin V and PI double positive cells represent late apoptotic cells; Annexin V single-positive cells represent early apoptotic cells; PI single-positive cells represent necrotic cells; and double-negative cells represent viable cells are shown in each group. (C) The differences of Annexin V-positive cells (early and late apoptotic status) was then analyzed between the treatment groups. Each data point represents the mean \pm SEM of 3 separate experiments. $\mathrm{P}<0.05$ and ${ }^{* * * *} \mathrm{P}<0.001$ indicate statistically significant differences compared to the control group.

examined by light microscopy. The TM3 cells shrank in size following treatment with $300 \mu \mathrm{M}$ propofol for $24 \mathrm{~h}$ (Fig. 1) and $350 \mu \mathrm{M}$ propofol for $3 \mathrm{~h}$ (Fig. 1); in addition, treatment with $400 \mu \mathrm{M}$ propofol for $3 \mathrm{~h}$ caused the detachment of most cells (Fig. 1). These results suggested that propofol can cause membrane blebbing in TM3 cells, which indicates that propofol can promote cell death possibly via apoptosis in TM3 mouse Leydig stem/progenitor cells.

Viability of TM3 cells is reduced by propofol in a time-and dose-dependent manner. The viability of TM3 cells affected by propofol was investigated by MTT assay. TM3 cells were treated with propofol (0 to $600 \mu \mathrm{M})$ for $1,3,6,12$ and $24 \mathrm{~h}$, respectively. The viability of the TM3 cells decreased significantly following treatment with propofol from 100 to $600 \mu \mathrm{M}$ for 6 to $24 \mathrm{~h}(\mathrm{P}<0.05)$ (Fig. 2). In fact, TM3 cell viability decreased to $49 \pm 8.1 \%$ with $300 \mu \mathrm{M}$ propofol for $12 \mathrm{~h}$ treatment (Fig. 2).

Propofol regulates the TM3 cell cell cycle. TM3 cells were treated with various concentrations of propofol $(0,100,300$ and $400 \mu \mathrm{M}$ ) for 3, 6, 12 and $24 \mathrm{~h}$, and the DNA contents in each treatment were investigated by flow cytometry. The data illustrated that the percentage of TM3 cells in the subG1 phase significantly increased by treatment with $400 \mu \mathrm{M}$ propofol for
3 to $24 \mathrm{~h}(\mathrm{P}<0.05)$ (Fig. 3A and B). Moreover, the percentage of TM3 cells in the G2/M phase markedly increased following treatment with $400 \mu \mathrm{M}$ propofol for 3 and $12 \mathrm{~h}(\mathrm{P}<0.05)$ (Fig. 3A and C).

Propofol induces the apoptosis of TM3 cells. The results revealed that propofol induced cell death with DNA fragmentation plus membrane blebbing and an increase in the number of TM3 cells in the subG1 phase. To further examine whether propofol induces the apoptosis of TM3 cells, Annexin V/PI double staining assay was used. It is acknowledged that percentages of double-positive cells (late apoptotic), Annexin V single-positive cells (early apoptotic), PI single-positive cells (necrotic) and double-negative cells (viable) are illustrated in 4 quadrants with the double staining illustrating different cell apoptotic phenomena (29). The cell distributions of viable, early apoptotic, necrotic and late apoptotic TM3 cells are illustrated in Fig. 4A, and the percentages of 4 different statuses among the cells treated with $0,300,350$ and $400 \mu \mathrm{M}$ propofol, respectively, are demonstrated in Fig. 4B. In addition, the number of Annexin V-positive TM3 cells (early and late apoptosis) was significantly induced by treatment with propofol at 350 and $400 \mu \mathrm{M}$ for $24 \mathrm{~h}(\mathrm{P}<0.05)$ (Fig. 4C). These data indicate that propofol induces the apoptosis of TM3 cells. 



Figure 5. Propofol activates the caspase cascade associated with the apoptosis of TM3 cells. Cells were treated with various concentrations of propofol (control, $300,350$ and $400 \mu \mathrm{M})$ for 3, 6, 12 and $24 \mathrm{~h}$, respectively. (A) Cleaved caspase-8 (43/18 kDa), cleaved caspase-9 (39/37 kDa), cleaved caspase-3 (17/19 kDa) and cleaved PARP (85-90 kDa) were examined by western blot analyses. The integrated optical densities (IOD) of (B) cleaved caspase-8, (C) cleaved caspase-9, (D) cleaved caspase- 3 and (E) cleaved PARP proteins were normalized to $\beta$-actin $(43 \mathrm{kDa})$ in each lane, respectively. Each data point represents the mean \pm SEM of 3 separate experiments. ${ }^{*} \mathrm{P}<0.05,{ }^{* *} \mathrm{P}<0.01$ and ${ }^{* * *} \mathrm{P}<0.001$ indicate statistically significant differences compared to the control group. $\mathrm{C}$, control.

Propofol activates the caspase cascade associated with the apoptosis of TM3 cells. The extrinsic and intrinsic caspase cascade is an imperative inducer of apoptotic pathway (30). As demonstrated above, propofol induced the apoptosis of TM3 cells. Thus, the present study then determined whether propofol induces apoptosis by activating caspase extrinsic and intrinsic pathways to induce the cleavage of caspase-9, caspase- 8 , caspase- 3 plus PARP. The results revealed that treatment with 350 and $400 \mu \mathrm{M}$ propofol for $3 \mathrm{~h}$ significantly induced the expression of cleaved caspase-8 (Fig. 5A and B). Treatment with 350 and $400 \mu \mathrm{M}$ propofol for 3 and $6 \mathrm{~h}$ also significantly induced the expression of cleaved caspase-9 (Fig. 5A and C), and treatment with $350 \mu \mathrm{M}$ propofol for $3 \mathrm{~h}$ and $400 \mu \mathrm{M}$ propofol for 3,6 and $12 \mathrm{~h}$ significantly induced the expression of cleaved caspase-3 (Fig. 5A and D). It was also found that treatment with $350 \mu \mathrm{M}$ propofol for $3 \mathrm{~h}$ significantly induced the expression of cleaved PARP $(\mathrm{P}<0.05)$ (Fig. 5A and E). These data illustrate that caspase pathways were activated by propofol to stimulate apoptosis in TM 3 cells.

It should be noted that treatment with $400 \mu \mathrm{M}$ propofol for $24 \mathrm{~h}$ significantly reduced the expression of cleaved PARP $(\mathrm{P}<0.05)$ (Fig. 5A and $\mathrm{E}$ ), suggesting that treatment of the TM3 cells for a long period of time with a high concentration of propofol suppressed the apoptotic phenomenon. In addition, the results revealed that treatment with $350 \mu \mathrm{M}$ propofol for $3 \mathrm{~h}$ activated the caspase cascade in TM3 cells (Fig. 5), but not in the MA-10 cells, as previously demonstrated (26), 

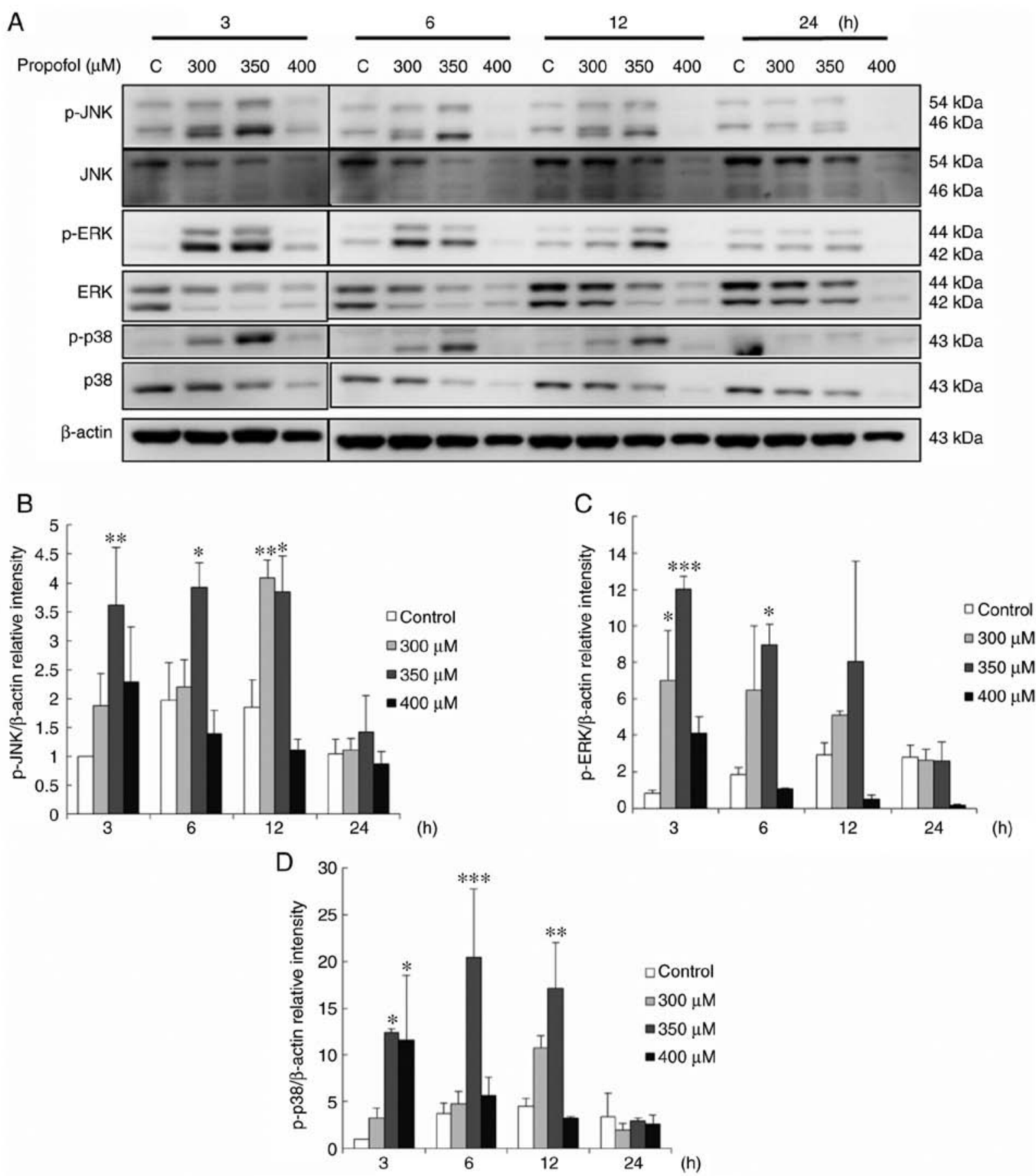

Figure 6. Propofol activates MAPK pathways associated with the apoptosis of TM3 cells. Cells were treated with various concentrations of propofol (control, 300, 350 and $400 \mu \mathrm{M}$ ) for 3, 6, 12 and $24 \mathrm{~h}$, respectively. (A) Phospho-JNK (p-JNK; 54/46 kDa), JNK (54/46 kDa), phospho-ERK (p-ERK; 44/42 kDa), ERK (44/42 kDa), phospho-p38 (p-P38; $43 \mathrm{kDa}$ ) and p38 (43 kDa) were examined by western blot analysis. The integrated optical densities (IOD) of (B) p-JNK, (C) p-ERK and (D) p-p38 proteins were normalized to $\beta$-actin $(43 \mathrm{kDa})$ in each lane, respectively. Each data point represents the mean \pm SEM of 3 separate experiments. ${ }^{*} \mathrm{P}<0.05,{ }^{* *} \mathrm{P}<0.01$ and ${ }^{* * * *} \mathrm{P}<0.001$ indicate statistically significant differences compared to the control group. $\mathrm{C}$, control.

suggesting that the TM3 cells are more sensitive to propofol compared to MA-10 cells.

Propofol activates MAPK pathways associated with the apoptosis of TM3 cells. A previous study demonstrated that the MAPK pathways control cell proliferation, growth and apoptosis (15). In the present study, to examine whether propofol regulates MAPK pathways to induce TM3 cell apoptosis, MAPK proteins were examined by western blot analysis. The results demonstrated that treatment with $300 \mu \mathrm{M}$ propofol for $12 \mathrm{~h}$ and $350 \mu \mathrm{M}$ propofol for 3,6 and $12 \mathrm{~h}$ significantly induced the expression of phospho-JNK $(\mathrm{P}<0.05)$ (Fig. 6A and B). In addition, treatment with $300 \mu \mathrm{M}$ propofol for $3 \mathrm{~h}$ and $350 \mu \mathrm{M}$ propofol for 3 and $6 \mathrm{~h}$ significantly induced the expression of phospho-ERK $(\mathrm{P}<0.05)$ (Fig. 6A and $\mathrm{C})$. It was also found that treatment with $350 \mu \mathrm{M}$ propofol for 3,6 and $12 \mathrm{~h}$, and $400 \mu \mathrm{M}$ propofol for $3 \mathrm{~h}$ significantly induced the expression of phospho-p38 $(\mathrm{P}<0.05)$ (Fig. 6A and $\mathrm{D})$. These data clearly 
A 3

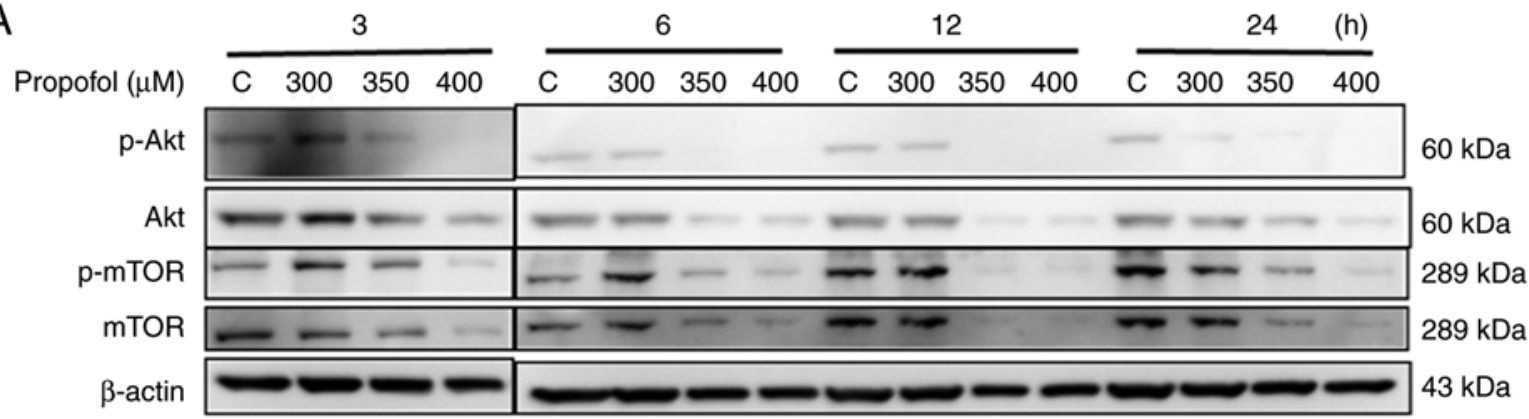

B

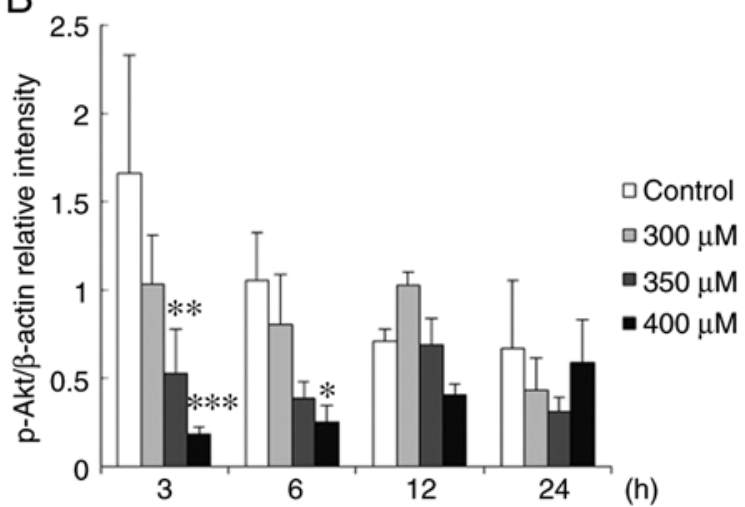

C

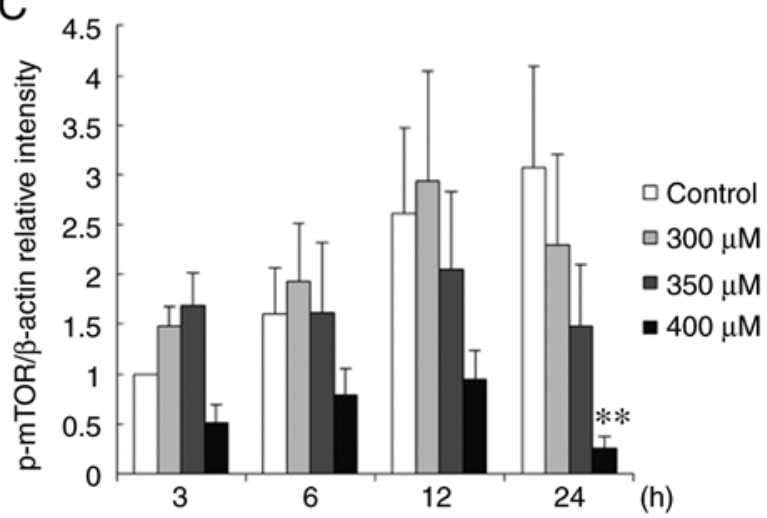

Figure 7. Propofol suppresses the Akt pathway associated with the apoptosis of TM3 cells. TM3 cells were treated with various concentrations of propofol (control, 300, 350 and $400 \mu \mathrm{M}$ ) for 3, 6, 12 and $24 \mathrm{~h}$, respectively. (A) Phospho-Akt (p-Akt; $60 \mathrm{kDa}$ ), Akt (60 kDa), phospho-mTOR (p-mTOR; $289 \mathrm{kDa})$ and mTOR (289 kDa) were examined by western blot analysis. The integrated optical densities (IOD) of (B) p-Akt and (C) p-mTOR proteins were normalized to $\beta$-actin $(43 \mathrm{kDa})$ in each lane, respectively. Each data point represents the mean $\pm \mathrm{SEM}$ of 3 separate experiments. ${ }^{*} \mathrm{P}<0.05$, ${ }^{* *} \mathrm{P}<0.01$ and ${ }^{* * *} \mathrm{P}<0.001$ indicate statistically significant differences compared to the control group. C, control.

illustrate that propofol activates MAPK pathways to stimulate the apoptosis of TM3 cells.

Propofol suppresses the Akt pathway associated with the apoptosis of TM3 cells. A previous study demonstrated that the Akt pathway inhibit apoptotic signal cascades and activate pro-survival signal cascades for cell survival (17). Thus, in the present study, to further examine whether propofol stimulates TM3 cell apoptosis through the inhibition of the Akt pathway, phospho-Akt, Akt, phospho-mTOR and mTOR expression patterns were examined by western blot analysis. The data demonstrated that treatment with $350 \mu \mathrm{M}$ propofol for $3 \mathrm{~h}$, and $400 \mu \mathrm{M}$ propofol for 3 and $6 \mathrm{~h}$ significantly reduced phospho-Akt expression $(\mathrm{P}<0.05)$ (Fig. 7A and $\mathrm{B})$. In addition, treatment with $400 \mu \mathrm{M}$ propofol for $24 \mathrm{~h}$ reduced phospho-mTOR expression $(\mathrm{P}<0.05)$ (Fig. 7A and C). These observations suggested that propofol induced apoptosis by inhibiting the Akt pathway in TM3 cells.

\section{Discussion}

A previous study indicated that propofol induced neurotoxicity (31). Moreover, studies have further demonstrated that propofol cause developmental neurotoxicity in mice $(2,3)$ and induces the apoptosis of neuronal stem cells in the hippocampus in neonatal mice (4). It is highly possible that propofol disrupts the development of Leydig stem/progenitor cells during the fetal and neonatal periods. Thus, in the present study, TM3 mouse Leydig stem/progenitor cells were used to examine the effects of propofol with a brief mechanistic investigation; it was found that propofol induced TM3 cell apoptosis.

Apoptosis is associated with intense transformations in the cellular architecture, and the activation of caspase cascades weakens the cell cytoskeleton, causing morphological modifications, such as membrane blebbing and cell shrinkage (32). The findings of the present study demonstrated that propofol induced membrane blebbing and cell shrinkage, illustrating that propofol affects the cytoskeleton and induces morphological changes to stimulate cell death associated with the apoptosis of TM3 cells. The authors have previously demonstrated that membrane blebbing occurs in MA-10 cells treated with a higher concentration $(400 \mu \mathrm{M})$ of propofol (26). However, in the present study, a lower concentration $(350 \mu \mathrm{M})$ of propofol was needed in the TM3 cells, indicating that the TM3 cells were more sensitive to propofol than the MA-10 cells. In a cell viability assay, it was observed TM3 cell viability decreased to $49 \%$ following treatment with $300 \mu \mathrm{M}$ propofol for $12 \mathrm{~h}$. However, as previously demonstrated, MA-10 cell viability decreased to $67 \%$ following treatment with $300 \mu \mathrm{M}$ propofol for $12 \mathrm{~h}$ (26). These phenomena indicate that the TM3 cells are more sensitive to propofol than the MA-10 cells, which is similar to the morphological results.

The substantial increase in subG1 phase cell numbers with propofol treatment illustrated that propofol regulates the distribution of the cell cycle to induce DNA fragmentation and the apoptosis of TM3 cells. Of note, propofol induced G2/M phase arrest in the TM3 cells, but not in the MA-10 cells (26). 
Previous studies have demonstrated that the increase in subG1 and G2/M phase arrest results in cell death through apoptosis $(33,34)$. Henceforth, the results of the present study suggest that propofol-induced apoptosis may be associated with cell cycle regulation.

In an Annexin V/PI double staining assay, the data also revealed the stimulation of apoptosis by propofol in a dose-dependent manner in TM3 cells, signifying that propofol actually induced TM3 cell apoptosis. However, propofol induced necrosis in TM3 cells in a dose-dependent manner, but not in the MA-10 cells (26). It has been shown that an overdose of propofol causes endothelial cytotoxicity by apoptosis plus necrosis (35). Thus, the findings of the present study are in accordance with those of other studies. It would be of interest to further investigate the mechanisms related to the stimulation of necrosis by propofol in TM3 cells.

It has been demonstrated that apoptosis principally commences by extrinsic and intrinsic signals, followed by the activation of the caspase cascade (11). The findings of the present study demonstrated that propofol activated caspase extrinsic and intrinsic signals to promote the apoptosis of TM3 cells. However, the same apoptotic effect with the activation of caspase pathways occurred in TM3 cells at a lower concentration $(350 \mu \mathrm{M})$ as in the MA-10 cells with a higher concentration (400 $\mu \mathrm{M})(26)$. Therefore, it was again observed that the TM3 cells were more sensitive to propofol than the MA-10 cells.

Studies have demonstrated that the MAPK pathways (ERK1/2, JNK and p38) regulated the apoptotic pathway to induce the apoptosis of various cell types (15,36-38). In fact, JNK can cause a shift to autophagy from apoptosis to regulate the survival of choriocarcinoma cells (37) and JNK can prevent the apoptosis of acute myeloid leukemia cells (39). It has also been demonstrated that ERK is able to promote apoptosis by facilitating cell cycle arrest in response to DNA damage in different cell types (38) and p38 can suppress caspase-3 activity in neural cells to induce apoptosis $(36,40)$. Studies have indicated that propofol can inhibit the MAPK pathways in different cell types to inhibit cell migration and inflammation $(41,42)$. The findings of the present study demonstrated that propofol significantly increased the phosphorylation of ERK, JNK and p38 in TM3 cells, suggesting that propofol can stimulate the MAPK pathways to induce the apoptosis of TM3 cells. It should be noted that propofol did reduce the expression of total MAPKs, as propofol induced p-JNK, p-ERK and p-p38 expression levels. These phenomena indicate that porpofol may cause the instability of MAPKs, which would result in MAPK degradation in TM3 cells. Further studies are warranted to reveal the underlying mechanisms.

Akt signaling can prevent the apoptotic signal and stimulate pro-survival signals to maintain cell survival (17). It has been demonstrated that PI3K/Akt pathway activation is highly associated with the formation of certain types of cancer (43). Actually, the function of propofol in the Akt pathway remains undetermined. Studies have found that propofol suppresses Akt signaling in macrophages to stimulate apoptosis (44), as propofol can activate the Akt pathway to protect rat cardiomyocytes from doxorubicin-induced toxicity (45). The present study found that propofol reduced the phosphorylation of Akt in TM3 cells. Thus, it is suggested propofol attenuates the activity of Akt and mTOR to stimulate the apoptosis of TM3 cells.

In conclusion, the present study demonstrates that propofol induces cell apoptosis through the activation of caspases and MAPKs pathways and the inhibition of the Akt pathway in TM3 Leydig stem/progenitor cells. This indicates that exposure to anesthetic agents can affect testicular normal Leydig cell development.

\section{Acknowledgements}

Not applicable.

\section{Funding}

The present study was supported by grants from the Ministry of Science and Technology MOST 105-2320-B-006028-MY3 (to BMH) and the Chi Mei-NCKU hospital grant CMNCKU10811 (to FCK and BMH), Taiwan, R.O.C.

\section{Availability of data and materials}

The data used and analyzed in this study are always accessible from authors on reasonable request.

\section{Authors' contributions}

FCK, YCC and SCW contributed to conducting all the experiments with statistical analysis. ECS and BMH contributed to all the experimental designs plus rationale setup, data analysis, manuscript writing, and ensuring the accuracy integrity of the whole study. All authors read and approved the final manuscript.

\section{Ethics approval and consent to participate}

Not applicable.

\section{Patient consent for publication}

Not applicable.

\section{Competing interests}

The authors declare that they have no competing interests.

\section{References}

1. Busettini $\mathrm{C}$ and Frolich MA: Effects of mild to moderate sedation on saccadic eye movements. Behav Brain Res 272: 286-302, 2014.

2. Jiang C, Logan S, Yan Y, Inagaki Y, Arzua T, Ma P, Lu S, Bosnjak ZJ and Bai X: Signaling network between the dysregulated expression of microRNAs and mRNAs in propofol-induced developmental neurotoxicity in mice. Sci Rep 8: 14172, 2018.

3. Logan S, Jiang C, Yan Y, Inagaki Y, Arzua T and Bai X: Propofol alters long non-coding RNA profiles in the neonatal mouse hippocampus: Implication of novel mechanisms in anesthetic-induced developmental neurotoxicity. Cell Physiol Biochem 49: 2496-2510, 2018.

4. Yan Y, Qiao S, Kikuchi C, Zaja I, Logan S, Jiang C, Arzua T and Bai X: Propofol induces apoptosis of neurons but not astrocytes, oligodendrocytes, or neural stem cells in the neonatal mouse hippocampus. Brain Sci 7: E130, 2017. 
5. Davidoff MS, Schulze W, Middendorff R and Holstein AF: The leydig cell of the human testis-a new member of the diffuse neuroendocrine system. Cell Tissue Res 271: 429-439, 1993.

6. Habert R, Lejeune $\mathrm{H}$ and Saez JM: Origin, differentiation and regulation of fetal and adult leydig cells. Mol Cell Endocrinol 179: 47-74, 2001.

7. Chen H, Ge RS and Zirkin BR: Leydig cells: From stem cells to aging. Mol Cell Endocrinol 306: 9-16, 2009.

8. Yu FX and Guan K: The Hippo pathway: Regulators and regulations. Genes Dev 27: 355-371, 2013.

9. Kroemer G, Galluzzi L, Vandenabeele P, Abrams J, Alnemri ES, Baehrecke EH, Blagosklonny MV, El-Deiry WS, Golstein P, Green DR, et al: Classification of cell death: Recommendations of the nomenclature committee on cell death 2009. Cell Death Differ 16: 3-11, 2009.

10. Kerr JF, Wyllie AH and Currie AR: Apoptosis: A basic biological phenomenon with wide-ranging implications in tissue kinetics. Br J Cancer 26: 239-257, 1972.

11. Oliveira JB and Gupta S: Disorders of apoptosis: Mechanisms for autoimmunity in primary immunodeficiency diseases. J Clin Immunol 1 (Suppl 28): S20-S28, 2008.

12. Lewis-Wambi JS and Jordan VC: Estrogen regulation of apoptosis: How can one hormone stimulate and inhibit? Breast Cancer Res 11: 206, 2009

13. Cossarizza A, Baccarani-Contri M, Kalashnikova G and Franceschi C: A new method for the cytofluorimetric analysis of mitochondrial membrane potential using the J-aggregate forming lipophilic cation 5,5',6,6'-tetrachloro-1,1',3,3'-tetraethylbenzimidazolcarbocyanine iodide (JC-1). Biochem Biophys Res Commun 197: 40-45, 1993.

14. Green DR and Reed JC: Mitochondria and apoptosis. Science 281: $1309-1312,1998$

15. Johnson GL and Lapadat R: Mitogen-activated protein kinase pathways mediated by ERK, JNK, and p38 protein kinases. Science 298: 1911-1912, 2002.

16. Son Y, Cheong YK, Kim NH, Chung HT, Kang DG and Pae HO Mitogen-activated protein kinases and reactive oxygen species: How can ROS activate MAPK pathways? J Signal Transduct 2011: 792639, 2011

17. Markman B, Dienstmann $\mathrm{R}$ and Tabernero J: Targeting the $\mathrm{PI} 3 \mathrm{~K} / \mathrm{Akt} / \mathrm{mTOR}$ pathway-beyond rapalogs. Oncotarget 1 : 530-543, 2010

18. Hein AL, Ouellette MM and Yan Y: Radiation-induced signaling pathways that promote cancer cell survival (review). Int J Oncol 45: 1813-1819, 2014

19. Zhou C, Zhao XM, Li XF, Wang C, Zhang XT, Liu XZ, Ding XF, Xiang SL and Zhang J: Curcumin inhibits AP- $2 \gamma$-induced apoptosis in the human malignant testicular germ cells in vitro. Acta Pharmacol Sin 34: 1192-1200, 2013.

20. Geigerseder C, Doepner RF, Thalhammer A, Krieger A and Mayerhofer A: Stimulation of TM3 Leydig cell proliferation via GABA(A) receptors: A new role for testicular GABA. Reprod Biol Endocrinol 2: 13, 2004.

21. Goldenberg RC, Fortes FS, Cristancho JM, Morales MM, Franci CR, Varanda WA and Campos de Carvalho AC: Modulation of gap junction mediated intercellular communication in TM3 leydig cells. J Endocrinol 177: 327-335, 2003.

22. Mather JP: Establishment and characterization of two distinct mouse testicular epithelial cell lines. Biol Reprod 23: 243-252, 1980.

23. Green LM, Reade JL and Ware CF: Rapid colorimetric assay for cell viability: Application to the quantitation of cytotoxic and growth inhibitory lymphokines. J Immunol Methods 70 : 257-268, 1984

24. Chang MM, Lai MS, Hong SY, Pan BS, Huang H, Yang SH, Wu CC, Sun HS, Chuang JI, Wang CY and Huang BM: FGF9/FGFR2 increase cell proliferation by activating ERK1/2, $\mathrm{Rb} / \mathrm{E} 2 \mathrm{~F} 1$ and cell cycle pathways in mouse leydig tumor cells. Cancer Sci 109: 3503-3518, 2018.

25. Kang FC, Wang SC, Chang MM, Pan BS, Wong KL, Cheng KS So EC and Huang BM: Midazolam activates caspase, MAPKs and endoplasmic reticulum stress pathways, and inhibits cell cycle and Akt pathway, to induce apoptosis in TM3 mouse leydig progenitor cells. Onco Targets Ther 11: 1475-1490, 2018.

26. Kang FC, Wang SC, So EC, Chang MM, Wong KL, Cheng KS, Chen YC and Huang BM: Propofol could increase caspases and MAPKs pathways and suppress Akt pathway to induce apoptosis in MA-10 mouse leydig tumor cells. Oncol Rep 41: 3565-3574, 2019.
27. Lowry OH, Rosebrough NJ, Farr AL and Randall RJ: Protein measurement with the folin phenol reagent. J Biol Chem 193: 265-275, 1951 .

28. Mu YF, Chen YH, Chang MM, Chen YC and Huang BM: Arsenic compounds induce apoptosis through the caspase pathway in MA-10 leydig tumor cells. Oncol Lett 18: 944-954, 2019.

29. van Engeland M, Ramaekers FC, Schutte B and Reutelingsperger CP: A novel assay to measure loss of plasma membrane asymmetry during apoptosis of adherent cells in culture. Cytometry 24: 131-139, 1996.

30. Creagh EM and Martin SJ: Caspases: Cellular demolition experts. Biochem Soc Trans 29: 696-702, 2001

31. Yu D, Jiang Y, Gao J, Liu B and Chen P: Repeated exposure to propofol potentiates neuroapoptosis and long-term behavioral deficits in neonatal rats. Neurosci Lett 534: 41-46, 2013.

32. Taylor RC, Cullen SP and Martin SJ: Apoptosis: Controlled demolition at the cellular level. Nat Rev Mol Cell Biol 9: 231-241, 2008.

33. Paul-Samojedny M, Suchanek R, Borkowska P, Pudelko A, Owczarek A, Kowalczyk M, Machnik G, Fila-Danilow A and Kowalski J: Knockdown of AKT3 (PKB $\gamma)$ and PI3KCA suppresses cell viability and proliferation and induces the apoptosis of glioblastoma multiforme T98G cells. Biomed Res Int 2014: 768181, 2014

34. Zhang C, Chen Z, Zhou X, Xu W, Wang G, Tang X, Luo L, Tu J, $\mathrm{Zhu} \mathrm{Y}, \mathrm{Hu} \mathrm{W}$, et al: Cantharidin induces $\mathrm{G} 2 / \mathrm{M}$ phase arrest and apoptosis in human gastric cancer SGC-7901 and BGC-823 cells. Oncol Lett 8: 2721-2726, 2014.

35. Lin MC, Chen CL, Yang TT, Choi PC, Hsing CH and Lin CF: Anesthetic propofol overdose causes endothelial cytotoxicity in vitro and endothelial barrier dysfunction in vivo. Toxicol Appl Pharmacol 265: 253-262, 2012.

36. Lee JM, Lee JM, Kim KR, Im H and Kim YH: Zinc preconditioning protects against neuronal apoptosis through the mitogen-activated protein kinase-mediated induction of heat shock protein 70. Biochem Biophys Res Commun 459: 220-226, 2015.

37. Shen Y, Yang J, Zhao J, Xiao C, Xu C and Xiang Y: The switch from ER stress-induced apoptosis to autophagy via ROS-mediated JNK/p62 signals: A survival mechanism in methotrexate-resistant choriocarcinoma cells. Exp Cell Res 334: 207-218, 2015.

38. Tang D, Wu D, Hirao A, Lahti JM, Liu L, Mazza B, Kidd VJ, Mak TW and Ingram AJ: ERK activation mediates cell cycle arrest and apoptosis after DNA damage independently of p53. J Biol Chem 277: 12710-12717, 2002.

39. Lin X, Fang Q, Chen S, Zhe N, Chai Q, Yu M, Zhang Y, Wang Z and Wang J: Heme oxygenase-1 suppresses the apoptosis of acute myeloid leukemia cells via the JNK/c-JUN signaling pathway. Leuk Res 39: 544-552, 2015.

40. Zhang B, Wu T, Wang Z, Zhang Y, Wang J, Yang B, Zhao Y, Rao Z and Gao J: p38MAPK activation mediates tumor necrosis factor- $\alpha$-induced apoptosis in glioma cells. Mol Med Rep 11: 3101-3107, 2015

41. Wu KC, Yang ST, Hsia TC, Yang JS, Chiou SM, Lu CC, Wu RS and Chung JG: Suppression of cell invasion and migration by propofol are involved in down-regulating matrix metalloproteinase-2 and p38 MAPK signaling in A549 human lung adenocarcinoma epithelial cells. Anticancer Res 32: 4833-4842, 2012.

42. Li D, Wang C, Li N and Zhang L: Propofol selectively inhibits nuclear factor- $\mathrm{\kappa B}$ activity by suppressing p38 mitogen-activated protein kinase signaling in human EA.hy926 endothelial cells during intermittent hypoxia/reoxygenation. Mol Med Rep 9: 1460-1466, 2014

43. Vivanco I and Sawyers CL: The phosphatidylinositol 3-Kinase AKT pathway in human cancer. Nat Rev Cancer 2: 489-501, 2002.

44. Hsing CH, Chen YH, Chen CL, Huang WC, Lin MC, Tseng PC, Wang CY, Tsai CC, Choi PC and Lin CF: Anesthetic propofol causes glycogen synthase kinase-3 $\beta$-regulated lysosomal/mitochondrial apoptosis in macrophages. Anesthesiology 116: 868-881, 2012.

45. Sun X, Gu J, Chi M, Li M, Lei S and Wang G: Activation of PI3K-Akt through taurine is critical for propofol to protect rat cardiomyocytes from doxorubicin-induced toxicity. Can J Physiol Pharmacol 92: 155-161, 2014. 